\title{
Framing the EU and the Green Deal in Estonia: A reluctant balancing act
}

\author{
MAILI VILSON \\ University of Tartu, Estonia \\ maili.vilson@ut.ee
}

\begin{abstract}
:
As the new government incorporating the populist EKRE party took office in Estonia in spring 2019, concerns emerged about Estonia's long-standing policy outlook of strong Euro-Atlantic integration. Other coalition members had to balance EKRE's policy positions, which manifested in contradictory statements and vague decisions. Analysing the Estonian government's rhetoric about the EU, this paper reveals how the government in its first year in office framed the European Union (EU). The Green Deal, or the EU's target of achieving climate neutrality by 2050, emerged as one of the cross-cutting topics in the discourse, but the pragmatic rhetoric employed by ministers and the conflict between values and actions raises questions about the motivations of the government, and therefore results in what is termed as 'reluctant' Europeanisation.
\end{abstract}

Key words: EU perceptions; Europeanisation; Estonia; Green Deal; populism

\section{Introduction}

An unexpected government took office in Estonia in the spring of 2019, after the winner of the election - the liberal Reform Party - was unable to find allies to form a government and was cast aside in favour of a coalition comprised of the left-leaning Centre Party (Keskerakond, KE), the populist radical right Conservative People's Party (Eesti Konservatiune Rahvaerakond, EKRE), and the right-wing Christian democratic Pro Patria (Isamaa, PP). This move brought Estonia to the centre of international attention as yet another European country to have joined the "far-right club" (Gershkovich, 2019). The government's first year in office was characterised by controversies in which statements made by members of $E K R E$ were mitigated and even overruled by other coalition partners. This led to misunderstandings about the government's positions both in Estonia and abroad (e.g. Vahtla, 2019a, 2019b). This article will focus on one aspect of this phenomenon - the policy towards the European Union (EU).

The coalition's EU policy started poorly. $K E$, the party of Prime Minister Jüri Ratas, had been grappling with accusations of being pro-Russian owing to its previous leadership's political stance and a strong supporter base among the Russian-speaking Estonians, which raised concerns about the continuity of Estonia's Euro-Atlantic course. The populist EKRE established itself as an anti-Russian, Eurosceptic and anti-immigration force promoting traditional family values (Kasekamp, Madisson \& Wierenga, 2019). PP, the minor partner in the coalition, perceived close integration with the West as a security 
guarantee for Estonia, but held conservative views, overlapping partly with those of $E K R E$. Therefore, immediately after assuming office, the new government had to provide public reassurances about Estonia's Euro-Atlantic outlook (Ots, 2019a) which had always been perceived as a given in Estonia's foreign policy.

Moreover, the government's public reiteration was crucial not only for foreign partners but also for the pro-EU domestic audience. The support for EU membership has been rather high in Estonia - between 65\% and 83\% from 2004 to 2017 (Austers, 2017) - and consistent across party lines. In 2019, 74\% of the population supported Estonia's EU membership, including $87 \%$ of $P P$ supporters, $74 \%$ of $K E$ and $54 \%$ of $E K R E$ voters (Ots, 2019b). EKRE, who employed anti-EU slogans in their rhetoric and belonged to the farright Identity and Democracy group in the European Parliament, had to ensure their message was acceptable to the non-Eurosceptic majority of the Estonian public.

In light of the above, this paper will add to the EU studies literature by providing a case study of the Estonian elites' narrative perceptions of the EU. It asks how did the government, in which remarkably different parties held diverse (if not incommensurable) views about the EU, frame its discourse? The paper proceeds in three parts. First, it will offer a brief overview of Estonia's Europeanisation to contextualise the positions of the government. This is followed by a methodological discussion on using framing and content analysis to study perceptions. Third, the paper presents findings from EU-related frames which emerged during the government's first year in office, and discusses the narrative of the Green Deal in particular. In doing so, the analysis shows both a continuity as well as a break from past governments in terms of discourse on the EU. While this can be associated with EKRE in particular, the findings are nuanced and suggest that a more reluctant and pragmatic (instrumental) EU policy is emerging in Estonia. The findings relate back to the argument about the functions of narratives (see Introduction to the Special Issue), as the Estonian case demonstrates the presence and negotiation of narrative on all three (system, identity and issue) levels (Miskimmon, O'Loughlin \& Roselle, 2013; Roselle, Miskimmon \& O'Loughlin, 2014).

\section{Estonia in the EU: from an eager student to a pragmatic Europeanist?}

Membership in the EU and NATO is the cornerstone of Estonia's foreign policy. Integration into the Western political and security structures is perceived as a security guarantee against Russia but also represents a more general cultural and political 'return to Europe' after the Soviet experiment (Kuus, 2007; Mälksoo, 2006). Estonia has been described as a poster child for successful post-communist transition (Kasemets, 2013; Mungiu-Pippidi, 2010), a 'top student' among the 2004 EU accession countries and a strong supporter of deeper integration and further enlargement after becoming a full member (Ehin, 2013). The country supported fiscal austerity measures after the 2011 financial crisis. It endorsed various European joint initiatives, such as the Eastern Partnership, where it consistently promoted its political preferences in an effort to shape EU policy (Kasekamp, 2013; Made, 2011). While the elite consensus has been firmly pro- 
European both before and after accession, the degree of Europeanisation has varied, depending on the specific policy domain. ${ }^{1}$

There is limited previous research on Estonia's preferences regarding EU climate policy. The national position can be characterised as constructive, yet ambiguous. For example, it has been shown that Estonia's compliance with EU policies has been driven by a sense of obligation and solidarity rather than the cause of environmentalism (Ehnert, 2019; Streimikiene, Ciegis \& Pusinaite, 2006). This is supported by the argument that principles such as being a constructive member and claiming solidarity with others are central to Estonia's EU policy planning (Raik, 2015, p. 449). The pragmatic stance to climate issues has been explained by Estonia's dependency on oil shale (Roos, Soosaar, Volkova \& Streimikene, 2012), which has not only economic, but also security, political and social implications (Maigre, 2010; Raudsepp, Heidmets \& Kruusvall, 2009). While the country has financially benefited from selling excess greenhouse gas emission credits under the EU Emissions Trading System, Estonia's political elite has not taken a clear stance on climate change, which can primarily be attributed to the lack of domestic political demand. As will be shown in the frame analysis below, climate issues merited only a passing mention in domestic debates before the European Commission's respective proposal. The sudden adoption of an Estonian climate neutrality target can be considered a pragmatic policy approach, rather than driven by shared norms and values.

\section{Framing the EU through government briefings}

Perceptions can be studied through a variety of approaches, but this paper considers those particularly useful, which consider the wider context of what is being communicated. Through the process of framing, actors "attribute meaning to the reality and interpret relevant information in specific ways" (Voltolini, 2016, p. 1504). Framing therefore points to an interaction between events or objects on the one hand, and our interpretation of them on the other, resulting in contestable meanings (Snow, Vliegenthart \& CorrigallBrown, 2007, p. 387). More than that, framing emphasises a distinct aspect of a perceived reality that "promote[s] a particular problem definition, causal interpretation, moral evaluation, and/or treatment recommendation" (Entman, 1993, p. 52). Through frames, actors can shape an understanding of social processes, and this in turn can influence behaviour. Therefore, how a government frames an issue may influence audiences' perception of both the issue itself as well as the government's policies.

This paper studies the government's discourse via core framing tasks (Snow \& Benford, 1988) which distinguish between three elements: diagnostic (how is the problem defined); evaluative (what are the potential solutions to the problem); and prescriptive (how is the problem treatment understood) (Entman, 1993; Matthes \& Kohring, 2008). The paper gives an overview of the Estonian government's EU frames first, and then focuses on the emergence of the Green Deal in particular.

The body of data for this research consists of transcripts of press briefings of the Estonian government's sessions during their first year in office (29 April 2019 to 30 April 2020). The government holds regular meetings on Thursdays and deliberates on various items such as draft legislation and EU matters within the purview of the government (including

\footnotetext{
${ }^{1}$ Following Radaelli (2002, p. 108), I define Europeanisation as “[p]rocesses of (a) construction (b) diffusion and (c) institutionalization of formal and informal rules, procedures, policy paradigms, styles, 'ways of doing things' and shared beliefs and norms which are first defined and consolidated in the making of EU public policy and politics and then incorporated in the logic of domestic discourse, identities, political structures and public policies".
} 
the adoption of legal acts). All sessions are followed by a press briefing, and both the transcripts as well as video recordings of the briefings are published online in Estonian (Vabariigi Valitsus, n.d.). At the briefing, three to four ministers (as a rule, at least one from each coalition party) present the items on the agenda. This is followed by a Q\&A with the press, during which the questions posed may or may not concern the agenda (journalists often inquire about other issues of interest).

Briefings are a valuable source for examining framing processes because they provide a regular snapshot of contemporary affairs and are particularly useful for following the evolution of policy positions. Full transcripts enable tracing of the exact words used yet provide the necessary context in which something is said. Although the immediate audience consists of a limited number of journalists, the accessibility of the briefings implies that the target audience is wider, including all citizens and foreign partners.

In using briefings as a data source, certain caveats apply, especially when compared to (news) media analysis. For example, the range of topics discussed at briefings is limited: the journalists may choose not to raise an issue at a briefing and may approach the ministers elsewhere and receive information that is not recorded. In some instances, media content analysis may be more appropriate for research than general briefings. In the news media, journalists can also provide fact-checking or context to claims made by speakers which may be lacking in the 'unedited' briefings.

Data was analysed through a combination of qualitative content and frame analysis (Krippendorff, 2019; Matthes \& Kohring, 2008; Snow, Vliegenthart \& Corrigall-Brown, 2007), which allows for the identification and organisation of broader themes in a text corpus by content analysis and helps to dissect particular topics according to framing tasks outlined above. The process of data collection and analysis was completed as follows: all transcripts were downloaded from the government's website and saved as plain text. Using AntConc software (v 3.5.8), general quantitative characteristics of the text corpus were obtained (see overview in Table 1). In the course of one year, 52 press briefings took place, including extraordinary sessions.

Table 1: Overview of text corpus (29 April 2019 - 30 April 2020)

\begin{tabular}{|c|c|c|c|c|c|}
\hline \multirow{2}{*}{$\begin{array}{l}\text { Total } \\
\text { number } \\
\text { of } \\
\text { briefings }\end{array}$} & \multirow{2}{*}{$\begin{array}{l}\text { Total } \\
\text { length of } \\
\text { briefings } \\
\text { (words) }\end{array}$} & \multirow{2}{*}{$\begin{array}{l}\text { Average length } \\
\text { per briefing } \\
\text { (words) }\end{array}$} & \multicolumn{3}{|c|}{ TOP5 speakers } \\
\hline & & & Name & $\begin{array}{l}\text { Number of } \\
\text { briefings attended }\end{array}$ & $\begin{array}{l}\text { Party affiliation, position } \\
\text { held in government }\end{array}$ \\
\hline \multirow[t]{5}{*}{52} & \multirow[t]{5}{*}{284,883} & \multirow[t]{5}{*}{5478.5} & Jüri Ratas & 40 & $K E$; Prime Minister \\
\hline & & & $\begin{array}{l}\text { Urmas } \\
\text { Reinsalu }\end{array}$ & 35 & $\begin{array}{l}P P \text {; Minister of Foreign } \\
\text { Affairs }\end{array}$ \\
\hline & & & $\begin{array}{l}\text { Mart } \\
\text { Helme }\end{array}$ & 25 & $\begin{array}{l}\text { EKRE; Minister of the } \\
\text { Interior }\end{array}$ \\
\hline & & & $\begin{array}{l}\text { Martin } \\
\text { Helme }\end{array}$ & 16 & $\begin{array}{lll}\text { EKRE; } & \text { Minister } & \text { of } \\
\text { Finance } & & \end{array}$ \\
\hline & & & Tanel Kiik & 15 & $\begin{array}{l}\text { KE; Minister of Social } \\
\text { Affairs }\end{array}$ \\
\hline
\end{tabular}

Source: Compiled by author 
Next, all transcripts were analysed qualitatively to identify speakers and topics to establish a thematic overview. In the same reading, the transcripts were marked for all mentions of Europe (Euroopa in Estonian) which included but were not limited to the EU (Euroopa Liit in Estonian). ${ }^{2}$ In the second reading, the Europe-related codes were analysed and organised under several labels which emerged from the texts, of which two pertained to the EU: 'EU Politics' (76 instances) and 'EU Regulatory' (28 instances). The label 'EU Politics' grouped all mentions of EU institutions and everyday decision-making, generating a rich pool of data for analysing the government's discourse. The statements in this sample were the most informative and illustrative of Estonia's positions on the EU decision-making and actorness. The label 'EU Regulatory' included references to EU legislation or national positions on the adoption of EU legal acts. The speakers usually presented these items in a matter-of-fact style without much discussion, which gave few additional thematic insights but contributed to the descriptive framing of the EU. Taken together, the labels helped to formulate a more precise EU frame, consisting of two elements - everyday politics of the EU and the EU as a regulator.

The final step of the analysis focused on the Green Deal in connection with national policies, a theme which emerged from the initial coding and intensified through time. The initiative was referred to in various formulations (such as 'climate', 'climate neutrality', 'environment', 'nature', 'Green Deal') and recurring contexts (e.g. (renewable) energy, transport, oil shale, North-East Estonia, greenhouse gas emission quota). Due to the widespread use of linguistic variations, no meaningful frequency analysis of the text corpus could be conducted, and the topic was explored through frame element analysis by identifying the diagnostic, evaluative and prescriptive dimensions.

\section{Estonian government's framing of the EU}

Overall, the EU is well represented in the governmental discourse (see Table 2): the keyword 'Europe' is present in all but one transcript, i.e. in 51 transcripts, and is most frequently associated with some variation of 'European Union' (349 instances, 55\% of all references to 'Europe').

Table 2. Frequency of 'Europe' in the text corpus

\begin{tabular}{|l|l|l|}
\hline $\begin{array}{l}\text { 'Europe' } \\
\text { (number of briefings) }\end{array}$ & $\begin{array}{l}\text { 'Europe' } \\
\text { (number of instances) }\end{array}$ & $\begin{array}{l}\text { 'European Union' } \\
\text { (number of instances) }\end{array}$ \\
\hline 51 & 628 & 349 \\
\hline
\end{tabular}

Source: Compiled by author

Findings indicate that the EU is a normal part of the everyday discourse of the government: it is mentioned in various contexts both directly and indirectly and there are no significant differences according to party affiliation or domains of responsibility. EU membership is presented as of key importance for Estonia, and the era of being an EU member as the most prosperous in its history. The discourse of the Eurosceptic EKRE is distinct and touches upon the core of Estonia's identity: EKRE emphasised on several occasions that the EU should be a union of sovereign countries and that no further federalisation should occur. The same was articulated in the coalition agreement and it is significant for two reasons: first, other coalition partners never refer to this in their

${ }^{2}$ The text corpus is in Estonian, but the article uses English translations for the sake of clarity. All translations by the author unless otherwise noted. 
statements, and second, the anti-federalist stance is more pronounced compared to previous governments who tended to offer at least rhetorical support for further integration. EKRE also criticised the EU for being too bureaucratic and centralised but did not contest either the EU itself or Estonia's membership. Kasekamp, Madisson \& Wierenga (2019, p. 52) have thus suggested that EKRE can be considered as a conditional Eurosceptic party who supports cooperating within the EU framework for as long as it does not threaten state sovereignty.

At the briefings, ministers also present national positions prior to the EU Council meetings and report on the results afterwards, sometimes highlighting the intergovernmental debates. This is a well-established routine and particularly observable in cases where the government has a vested interest in showcasing their viewpoint or gathering public support. For example, in the case of the discussion on the migration agreement in autumn 2019, Minister of the Interior Mart Helme laid out different views among EU member states, in order to demonstrate that Estonia was not alone in its (antiimmigration) position and to underline the conflicting opinions that gave Estonia room to manoeuvre (Vabariigi Valitsus, 2019e). Notwithstanding the precise motivation of ministers for reporting about EU meetings at the briefings, this does show the prominence of the EU in the discourse. ${ }^{3}$

The most frequent topics in the EU dataset included the Green Deal, Brexit, Cohesion Fund allocations, the Multiannual Financial Framework and, more recently, Covid-19related financial initiatives. In sum, finances appeared as a central theme throughout the discourse: EU initiatives were accompanied by a cost-benefit calculation and budget negotiations always addressed the fairness of structural funds distribution. Some government members expressed frustration over the fact that EU funds were designated for a particular purpose, which, in the words of Minister of the Interior Mart Helme, could result in "pan-European scheming" for money (Vabariigi Valitsus, 2020a). Overall, this highlights two interconnected points: first, Estonia's overreliance on EU funds in the state budget, and, second, the perception of the EU as a source of money. In this context, the EU funds can be perceived as instrumental in helping the Estonian elites to maintain power, but they may also promote the idea of Europe and increase the EU's presence in a member state. This will be explored further in the case of the Green Deal which quite abruptly emerged in the Estonian government's discourse.

\section{Estonia's turn towards the Green Deal}

The European Green Deal (EGD) is the EU's initiative for tackling climate change by becoming the first climate-neutral continent by 2050, proposed by the European Commission in July 2019. Shortly before, in June 2019, the EU failed to commit to climate neutrality because four member states, including Estonia, opposed setting net-zero by 2050 as an EU-wide legally binding target. The Estonian government justified its position by arguing that it did not want to commit to unrealistic goals. However, following negative international and domestic media coverage (e.g. Tamma \& Barigazzi, 2019; Teffer, 2019), the Estonian government completely changed its position in July 2019. The shift in rhetoric was unexpected because there was neither a clear position on climate policies by the coalition parties, nor any significant popular demand for it. Kleinberga (2020) observes a similar trend in Latvia in this Special Issue. Only the populist EKRE had

\footnotetext{
${ }^{3}$ Various strands of literature offer explanations as to why the politicians would seek to display their activities on the EU level back home, be it gaining electoral support, socialization (Europeanisation), etc. These cannot be explored here but see e.g. Ilonszki, 2010).
} 
previously argued that the reasons for global warming were unclear and that they would consider leaving the Paris Agreement (Krjukov, 2019).

The coverage of climate issues during the Estonian government's first year in office can be divided into two phases: the pre-EGD period (from May 2019 to mid-July 2019), when climate neutrality was barely addressed; and the EGD-period (from mid-July 2019 onwards), when it was elevated to the centre of government's discourse.

During the first phase, the government's climate policy was close to non-existent, which was manifested by a discussion at one of the first government briefings. Prime Minister Ratas $(K E)$ commented on the issue of climate change by saying that "[it] needs to be addressed...We can all do it by reducing our carbon footprint" (Vabariigi Valitsus, 2019a). Reacting to this, Minister of Finance Martin Helme (EKRE) appeared to deny anthropogenic global warming by stating that "[the fact] that we have ice ages and warmer ages has not been proven to be connected to human activity, despite great efforts." (Vabariigi Valitsus, 2019a) Foreign Minister Urmas Reinsalu ( $P P$ ) responded to these statements by remarking on the importance of pure nature as a national treasure (Vabariigi Valitsus, 2019a). In sum, there were only few mentions of climate issues and no government positions on the topic during the pre-EGD period, which significantly limits the data for frame element analysis. As shown above, of the three coalition partners, EKRE dismissed climate change as a problem, while $K E$ and $P P$ diagnosed climate change as a problem in general terms but offered little substance regarding evaluation (what can be done to solve the problem) or prescriptions (how should these measures be weighed). It can be concluded that neither the Estonian government as a whole nor individual coalition partners had a clear stance on climate neutrality when it emerged on the EU agenda in June 2019.

The situation changed less than a month after the failure to agree on the climate neutrality target by 2050 in the European Council when Prime Minister Ratas announced the establishment of a new governmental commission for climate and energy and declared climate change a political priority (Estonian Government, 2019). It was framed as a national initiative without any reference to the EU or the EGD. From here onwards, the question of climate neutrality by 2050 and the implications for achieving it in Estonia became a regular theme in the government's rhetoric. This will be addressed in the following frame element analysis of the EGD-period (see Table 3 for summary).

In terms of the first frame element - diagnosis of the problem - no clear view about the roots of climate change could be detected, which can be explained by the diverging opinions outlined above. Speakers referred to the "changing paradigm in the world [about climate change]" (Vabariigi Valitsus, 2019b) and to an agreement by the coalition that the issue needed to be addressed (Vabariigi Valitsus, 2019c). The second frame element, focusing on the evaluation of policy responses, was mostly presented through achieving two main targets: decreasing greenhouse gas emissions by $7 \%$ by 2030 and achieving climate neutrality by 2050 in line with the EGD. Ministers juxtaposed measures from the electrification of public transport to increasing various alternative energy sources with incurring high costs (Vabariigi Valitsus, 2019d). As regards the third element presentation/rejection of the proposed solution(s) - the government explained their reluctant stance by emphasising the specific conditions of Estonia which were in contradiction to the goals of the EGD. Estonia's main source of greenhouse gas emission is oil shale (OECD, 2017), yet multiple sectors rely on its supply: it guarantees energy security, contributes to the economy, sustains the mining industry, and thereby provides 
social stability. Proposing changes that could interrupt the (socio)economic system would be a highly unpopular move for any government.

Table 3. Frame element analysis of the government's discourse on the European Green Deal

\begin{tabular}{|c|c|c|}
\hline $\begin{array}{l}\text { Diagnosis } \\
\text { What caused the problem of } \\
\text { climate change? }\end{array}$ & $\begin{array}{l}\text { Evaluation } \\
\text { What are the solutions/ } \\
\text { responses to the problem? }\end{array}$ & $\begin{array}{l}\text { Prescription } \\
\text { How to evaluate the } \\
\text { solutions/ responses? }\end{array}$ \\
\hline $\begin{array}{l}\text { Climate change is real/ The } \\
\text { changing paradigm forces } \\
\text { Estonia to respond } \\
\text { No clear views on whether } \\
\text { climate change is human- } \\
\text { induced }\end{array}$ & $\begin{array}{l}\text { Meeting greenhouse gas } \\
\text { emission target for 2030, } \\
\text { achieving climate neutrality } \\
\text { by } 2050 \\
\text { Comprehensive EGD package } \\
\text { with adequate compensation }\end{array}$ & $\begin{array}{l}\text { High economic and social } \\
\text { transaction costs } \\
\text { Not enough funds to } \\
\text { compensate for the socio- } \\
\text { economic implications of the } \\
\text { transformation; } \\
\text { Mixed messages of values and } \\
\text { actions, instrumentalisation } \\
\text { of EGD }\end{array}$ \\
\hline
\end{tabular}

Source: Compiled by author

Therefore, while EU policymakers presented the EGD as a solution, the Estonian government perceived it as an obligation, above all, owing to the need to address sensitive and long-term structural problems. The government's key message was to insist on adequate compensation from the proposed Just Transition Fund to guarantee a fair socioeconomic transformation to a low-carbon economy. Yet, while the government acknowledged the importance of shared values and commitment to climate neutrality in rhetoric, its actions such as the establishment of a shale oil plant and pre-refinery or lowering the excise duty on diesel (Vabariigi Valitsus, 2020b) conflicted with these goals, thereby raising questions about the underlying motivations. The climate-sceptic EKRE spoke directly to the reasons behind the government's approach. During a weekly media appearance to their audience, EKRE ministers declared climate change an imported problem and, although EGD measures were regarded as drastic, argued that it was reasonable not to block the EGD but seek to benefit from it (Uued Uudised, 2019). To sum up, despite the prominence of climate issues during the EGD period, the government's rhetoric about EGD was vague and reluctant at best.

\section{Conclusion}

This article has presented the study of elite perceptions of the EU in the case of Estonia's first government to include a populist right-wing party $E K R E$. On the one hand, findings show that the EU was normalised in the government's rhetoric. The Eurosceptic EKRE seized the opportunity to communicate its views to the public, and while it may have disturbed what appeared a common-sense and generally supported approach to the EU, this did not result in major changes to Estonia's EU policies or contestation of EU membership.

On the other hand, the level of commitment to the goals of the EU on the part of the Estonian elites has to be questioned as the government's approach indicated 'reluctant' Europeanisation. The European Green Deal was not a priority for the Estonian government, despite explicit attempts to frame it otherwise. There were compelling 
socioeconomic reasons for the lack of enthusiasm on climate neutrality, and net-zero initiatives were perceived by the government as obligations or as a means to more pragmatic politics, without indicating a broader sense of alignment with the EU's norms and values. The findings from the Estonian case add to the existing literature on the process of Europeanisation in the current European political context. The paper shows that the existing pro-European narrative can be renegotiated into a more reluctant one. However, more research is needed to disentangle the complex relationship between European integration, the rise of populism in the EU and the political and economic transition in Central and Eastern Europe.

\section{References}

Austers, A. (2017). Euroscepticism in the Baltic states. Much ado about nothing? Friedrich-Ebert Stiftung Riga.

Ehin, P. (2013). Estonia: Excelling at Self-Exertion. In C. Lequesne \& S. Bulmer (Eds.), The Member States of the European Union (pp. 213-235). Oxford University Press.

Ehnert, F. (2019). Climate Policy in Denmark, Germany, Estonia and Poland. Edward Elgar Publishing.

Entman, R. M. (1993). Framing: Toward Clarification of a Fractured Paradigm. Journal of Communication, 43(4), 51-58.

Estonian Government. (2019). Government identified climate issues as political priority. 25 July. https://www.valitsus.ee/en/news/government-identifiedclimate-issues-political-priority

Gershkovich, E. (2019). Estonia joins the far-right club. POLITICO, 30 April. https://www.politico.eu/article/estonia-tallinn-joins-the-far-right-club-martinhelme-mart-helme-kersti-kaljulaid-populism/

Ilonszki, G. (Ed.). (2010). Perceptions of the European Union in New Member States: A Comparative Perspective. Routledge.

Kasekamp, A. (2013). Estonia: Eager to Set an Example in Europe. In M. Baun \& D. Marek (Eds.), The New Member States and the European Union: Foreign Policy and Europeanization (pp. 99-111). Routledge.

Kasekamp, A., Madisson, M.-L., \& Wierenga, L. (2019). Discursive Opportunities for the Estonian Populist Radical Right in a Digital Society. Problems of PostCommunism, 66(1), 47-58.

Kasemets, A. (2013). Top of the Class. The Case of Estonia. In A. Mungiu-Pippidi (Ed.), Controlling Corruption in Europe. The Anticorruption Report (Vol. 1, pp. 6873). Verlag Barbara Budrich.

Krippendorff, K. (2019). Content analysis: An introduction to its methodology (4th Ed.). SAGE.

Krjukov, A. (2019). Helme: Kaaluksime Pariisi kliimaleppest lahkumist. ERR, 21 February. https://www.err.ee/913158/helme-kaaluksime-pariisi-kliimaleppestlahkumist 
Kuus, M. (2007). Geopolitics Reframed: Security and Identity in Europe's Eastern Enlargement. Palgrave Macmillan US.

Made, V. (2011). Shining in Brussels? The Eastern Partnership in Estonia's Foreign Policy. Perspectives, 19(2), 67-79.

Maigre, M. (2010). Energy Security Concerns of the Baltic States. International Centre for Defence Studies.

Mälksoo, M. (2006). From Existential Politics Towards Normal Politics? The Baltic States in the Enlarged Europe. Security Dialogue, 37(3), 275-297.

Matthes, J., \& Kohring, M. (2008). The Content Analysis of Media Frames: Toward Improving Reliability and Validity. Journal of Communication, 58(2), 258-279.

Miskimmon, A., O’Loughlin, B., \& Roselle, L. (2013). Strategic Narratives: Communication Power and the New World Order. Routledge.

Mungiu-Pippidi, A. (2010). Twenty Years of Postcommunism: The Other Transition. Journal of Democracy, 21(1), 120-127.

OECD. (2017). Environmental Performance Reviews: Estonia 2017.

Ots, M. (2019a). Ratas: Eesti on jätkuvalt Euroopa-meelne. ERR, 1 May. https://www.err.ee/935209/ratas-eesti-on-jatkuvalt-euroopa-meelne

Ots, M. (2019b). Uuring: Toetus EL-i kuulumisele on referendumiga võrreldes märgatavalt kasvanud. ERR, 29 October. https://www.err.ee/997153/uuringtoetus-el-i-kuulumisele-on-referendumiga-vorreldes-margatavalt-kasvanud

Radaelli, C. M. (2002). The domestic impact of European Union public policy: Notes on concepts, methods, and the challenge of empirical research. Politique Europeenne, 5(1), 105-136.

Raik, K. (2015). Renaissance of realism, a new stage of Europeanization, or both? Estonia, Finland and EU foreign policy. Cooperation and Conflict, 5O(4), 440456.

Raudsepp, M., Heidmets, M., \& Kruusvall, J. (2009). Environmental Justice and Sustainability in Post-Soviet Estonia. In J. Agyeman \& Y. Ogneva-Himmelberger (Eds.), Environmental Justice and Sustainability in the Former Soviet Union (pp. 215-236). MIT Press.

Roos, I., Soosaar, S., Volkova, A., \& Streimikene, D. (2012). Greenhouse gas emission reduction perspectives in the Baltic States in frames of EU energy and climate policy. Renewable and Sustainable Energy Reviews, 16(4), 2133-2146.

Roselle, L., Miskimmon, A., \& O’Loughlin, B. (2014). Strategic narrative: A new means to understand soft power. Media, War \& Conflict, 7(1), 70-84.

Snow, D. A., \& Benford, R. D. (1988). Ideology, Frame Resonance, and Participant Mobilization. In B. Klandermans, H. Kriesi, \& S. G. Tarrow (Eds.), From structure to action: Comparing social movement research across cultures: Vol 1. International social movement research (pp. 197-217). JAI Press. 
Snow, D. A., Vliegenthart, R., \& Corrigall-Brown, C. (2007). Framing the French Riots: A Comparative Study of Frame Variation. Social Forces, 86(2), 385-415.

Streimikiene, D., Ciegis, R., \& Pusinaite, R. (2006). Review of climate policies in the Baltic States. Natural Resources Forum, 30(4), 280-293.

Tamma, P., \& Barigazzi, J. (2019). Behind 4 countries' resistance to an EU climate neutral goal. POLITICO, 25 June. https://www.politico.eu/article/whats-behindthe-resistance-of-four-countries-to-an-eu-climate-neutral-goal-of-2050/

Teffer, P. (2019). Four states block EU 2050 carbon neutral target. EUobserver, 20 June. https://euobserver.com/environment/145227

Uued Uudised. (2019). 'Räägime asjast': Kliimavõitlus meenutab bolševike sõjakommunismi ja hilisemat rahuliikumist. Uued Uudised, 6 October. https://uueduudised.ee/uudis/eesti/raagime-asjast-kliimavoitlus-meenutabbolsevike-sojakommunismi-ja-hilisemat-rahuliikumist/

Vabarïgi Valitsus. (n.d.). Retrieved 24 May 2020, from https://www.valitsus.ee/et

Vabariigi Valitsus. (2019a). Vabariigi Valitsuse pressikonverentsi stenogramm, 23. mai 2019. https://www.valitsus.ee/et/uudised/vabariigi-valitsuse-pressikonverentsistenogramm-23-mai-2019

Vabariigi Valitsus. (2019b). Vabariigi Valitsuse pressikonverentsi stenogramm, 4.juuli 2019. https://www.valitsus.ee/et/uudised/vabariigi-valitsuse-pressikonverentsistenogramm-4-juuli-2019

Vabariigi Valitsus. (2019c). Vabarïgi Valitsuse pressikonverentsi stenogramm, 11.juuli 2019. https://www.valitsus.ee/et/uudised/vabariigi-valitsuse-pressikonverentsistenogramm-11-juuli-2019

Vabariigi Valitsus. (2019d). Vabarïgi Valitsuse pressikonverentsi stenogramm, 3. oktoober 2019. https://www.valitsus.ee/et/uudised/vabariigi-valitsusepressikonverentsi-stenogramm-3-oktoober-2019

Vabariigi Valitsus. (2019e). Vabarïgi Valitsuse pressikonverentsi stenogramm, 10. oktoober 2019. https://www.valitsus.ee/et/uudised/vabariigi-valitsusepressikonverentsi-stenogramm-10-oktoober-2019

Vabariigi Valitsus. (2020a). Valitsuse pressikonverentsi stenogramm, 20. veebruar 202O. https://www.valitsus.ee/et/uudised/valitsuse-pressikonverentsistenogramm-20-veebruar-2020

Vabariigi Valitsus. (2020b). Vabarïgi Valitsuse pressikonverentsi stenogramm, 19. märts 202O. https://www.valitsus.ee/et/uudised/vabariigi-valitsusepressikonverentsi-stenogramm-19-marts-2020

Vahtla, A. (2019a). Bahouski: Who is at the helm of Estonian foreign policy? ERR, 24 July. https://news.err.ee/964266/bahovski-who-is-at-the-helm-of-estonianforeign-policy 
Vahtla, A. (2019b). Mart Helme congratulates UK's Boris Johnson on becoming next prime minister. ERR, 24 July. https://news.err.ee/964200/mart-helmecongratulates-uk-s-boris-johnson-on-becoming-next-prime-minister

Voltolini, B. (2016). Non-state actors and framing processes in EU foreign policy: The case of EU-Israel relations. Journal of European Public Policy, 23(10), 15021519. 